Article

\title{
"It's Not Equality": How Race, Class, and Gender Construct the Normative Religious Self among Female Prisoners
}

\author{
Rachel Ellis \\ Department of Criminology \& Criminal Justice, University of Missouri-St. Louis, St. Louis, MO 63121, USA; \\ E-Mail: rellis@umsl.edu
}

Submitted: 16 January 2018 | Accepted: 9 March 2018 | Published: 22 June 2018

\begin{abstract}
Prior sociological research has demonstrated that religious selves are gendered. Using the case of female inmates-some of the most disadvantaged Americans-this article shows that dominant messages constructing the religious self are not only gendered, but also deeply intertwined with race and class. Data from 12 months of ethnographic fieldwork on religion inside a U.S. state women's prison reveal that religious volunteers-predominately middle-class African American women-preached feminine submissiveness and finding a "man of God" to marry to embody religious ideals. However, these messages were largely out of sync with the realities of working class and poor incarcerated women, especially given their temporary isolation from the marriage market and the marital prospects in the socioeconomically disadvantaged neighborhoods to which many would return. These findings suggest that scholars must pay attention to how race, class, and gender define dominant discourses around the religious self and consider the implications for stratification for those who fail to fulfill this dominant ideology.
\end{abstract}

\section{Keywords}

class; gender; prison; race; religion; religious self; stratification

Issue

This article is part of the issue "Complex Religion: Intersections of Religion and Inequality", edited by Melissa J. Wilde (University of Pennsylvania, USA).

(C) 2018 by the author; licensee Cogitatio (Lisbon, Portugal). This article is licensed under a Creative Commons Attribution 4.0 International License (CC BY).

\section{Introduction}

Prior sociological research has shown that religious selves are gendered (Avishai, 2008; Cadge, 2004; Rao, 2015; Schnabel, 2017a; Shahar, 2015). Using the case of female inmates-some of the most disadvantaged Americans - this article shows that religious selves are not only gendered, but also deeply intertwined with race and class. Data from a 12-month ethnography on religion inside a U.S. state women's prison reveal that religious volunteers-predominately middle-class African American women-preached feminine submissiveness and finding a "man of God" to marry to embody religious ideals. However, these messages were largely out of sync with the realities of working class and poor incarcerated women, especially given their temporary isolation from the marriage market and the marital prospects in the so- cioeconomically disadvantaged neighborhoods to which many inmates would return.

This article contributes to scholarship on the construction of religious selves in three ways. First, to understand how individuals define their religious selves requires an intersectional approach involving race, class, and gender. Second, context matters in interrogating how religious leaders shape discourses around the construction of religious selves. Finally, top-down expectations around religious selves could reinforce stratification, as they involve embodying ideals that may be out of reach for the least advantaged adherents. Overall, scholars must pay attention to how race, class, and gender define dominant discourses around the religious self and must consider the implications for inequality for those who fail to fulfill this ideology. 


\section{Literature Review}

\subsection{Doing Gender and the Construction of the Religious Selves}

Sociological research on religion in the past decade has convincingly demonstrated that "doing religion" inextricably intertwined with "doing gender" (Avishai, 2008; Cadge, 2004; Rao, 2015; Schnabel, 2017b; Shahar, 2015). "Doing religion", as defined by Avishai (2008, pp 413, $409)$, is a "semi-conscious, self-authoring project" in which individuals "search for authentic religious subjecthood". That is to say, in much the same way that gender is constructed and performed in everyday life through interaction and embodiment (Butler, 1990; West \& Zimmerman, 1987), an individual's "religious self" is constructed and performed in a manner consistent with gender norms. Constructing one's religious self is a bottomup project (Avishai, 2008) that occurs within the context of available, top-down gendered religious scripts (Davidman, 1991; Ingersoll, 2003; Mahmood, 2004; Rao, 2015; Sumerau \& Cragun, 2014).

Scholarship on the gendered religious self emphasizes its implications for gender inequality. Research on women in conservative religions (Avishai, 2016; Burke, 2012; Rao, 2015) grapples with whether women's participation in conservative religions resists or reinforces patriarchal ideology. A smaller body of research has considered the gendered religious self among men (Bartkowski, 2004; Heath, 2003; Rao, 2015; Smilde, 2007; Sumerau, 2012). Some scholars caution that conservative religions sacralize gender differences that promote feminine subordination (Chong, 2006; Sumerau \& Cragun, 2014; Sumerau, Cragun, \& Mathers, 2016). From this perspective, women's engagement in conservative religions reinforces inequality, whether advertently or inadvertently. Others argue that gender-specific religious engagement is an active and empowered choice (Avishai, 2008; Casselberry, 2017; Mahmood, 2004; Nyhagen, 2017; Ozorak, 1996; Prickett, 2015; Shahar, 2015; Yanay-Ventura, 2016). From this perspective, women's decisions around clothing, body rituals, and daily practices demonstrate agentic religious engagement rather than submission to men's rules. Both perspectives agree that negotiation of these issues is part and parcel of the embodiment of a gendered religious self (Ecklund, 2003; Ellis, 2017b; Mahmood, 2004; Zion-Waldoks, 2015).

Missing from this scholarship is a thorough consideration of the role of race and class in shaping the gendered religious self. As Avishai, Jafar and Rinaldo (2015) comment in an introduction to their special issue on gender research in religion:

We suggest that gender and religion scholarship would benefit from theoretical perspectives that build on current theories in the sociology of gender, including conceptualizing gender and sexuality...as profoundly relational and intersecting with other cate- gories such as race and class. (Avishai, Jafar, \& Rinaldo, 2015, p. 13)

Just as those studying women in conservative religions debate whether women's participation in conservative religious practices reflects patriarchy given the broader context of gender inequality, we should interrogate whether the performance of the religious self reflects, resists, or reinforces broader structural inequality around race, class, and gender.

\subsection{Why Intersectionality Matters for the Religious Self}

An intersectional approach to the religious self would examine how individuals construct their religious selves where key identities overlap, especially regarding race, class, and gender (Collins, 2000; Crenshaw, 1989, 1991; McCall, 2001; Spelman, 1988; West \& Fenstermaker, 2002). While many studies have considered the relationships between religion and race (Chatters, Taylor, \& Lincoln, 1999; Mattis, 2002), class (Keister, 2003, 2008, 2011; McCloud, 2007; Pyle, 2006; Smith \& Faris, 2005; Tevington, in press), and religion and gender (Fowler, Hertzke, Olson, \& Den Dulk, 2013; Green, 2007; Kaufmann \& Petrocik, 1999; Roth \& Kroll, 2007; Stark, 2002), far fewer have considered the intersections of these dimensions-what Wilde and Glassman (2016) call "complex religion". An intersectional approach to religion is important because "one cannot study religion independently of race and class in the US" (Wilde \& Glassman, 2016, p. 409) because "religion has been and continues to be a place of stark segregation by race, ethnicity, and class" (Wilde \& Glassman, 2016, p. 408). We know that the gendered religious self shapes political attitudes (Baker \& Whitehead, 2016; Schnabel, 2017b), career decisions (Leamaster \& Subramaniam, 2016), dating and marriage attitudes (Irby, 2014; Rao, 2015), sartorial choices (Bartkowski \& Ghazal-Read, 2003; Rao, 2015), and family relationships (Bulanda, 2011). Similarly, the intersectional religious self is likely to shape important individual-level outcomes related to politics, family, work, and the presentation of self.

Intersectionality is more than a simple additive calculation of the effects of race, class, and gender on religious behavior (cf. McCall, 2001; Singh, 2015), but rather, its "raison d'être lies in its attentiveness to power relations and social inequalities" (Collins, 2015, p. 1). A central aim of intersectionality is to elucidate the "interlocking" oppressions of sexism, racism, and classism (Crenshaw, 1991; Spelman, 1988). A handful of studies measure how ethnicity, class, and gender shape level of religious participation (Karim, 2008; Schnabel, 2015), or how racial identification is shaped by religion, class and gender (Davenport, 2016; Karim, 2008). Fewer interrogate how these variables shape the "power relations" and "social inequalities" that Collins (2015) called for. While scholars have started to chip away at the ways religion interacts with race, class, and gender, we have yet to interrogate 
how these intersections come to bear on intersectionality's primary project of understanding inequality.

The few existing studies on intersectionality, religion, and inequality tell us a great deal about how individuals draw upon competing identities to shape their religious selves. We know, for instance, the ways black Muslim women buffer themselves against oppression by carving out space for meaningful religious engagement (Prickett, 2015) and seeking solace in their religious community (Byng, 1998). Likewise, we understand that individuals shape their religious selves by drawing upon normative ideals, as in the case of Muslim women in Pakistan who signaled their educational attainment to mark themselves as "good" Muslims (Khurshid, 2015). However, like the literature on gendered religious selves, these scholars examine bottom-up ways individuals define themselves based on intersecting identities. While crucial, we must also directly interrogate the contexts in which individuals make decisions on how to do religion.

This article frames the discussion to ask how topdown religious messages shape the normative ways individuals construct and embody religious selves. The intersectional religious self is not constructed in a vacuum. The environment in which adherents "do religion" exists within a broader landscape of stratification and depends in large part upon the religious lessons they absorb. I find that religious teachers rely on their perceptions and expectations around race, class, and gender when describing the "ideal" religious self. These expectations could reinforce stratification, since the normative religious self embodies ideals that may be out of reach for disadvantaged adherents. This finding helps move literature on gendered religious selves closer to an intersectional approach, examining how race and class interact alongside gender to construct the religious self.

\section{Methods}

I spent twelve months conducting ethnographic fieldwork inside a state women's prison that I call Mapleside Prison (all names are pseudonyms) from April 2014 to May 2015. Mapleside Prison represents a typical U.S. state women's prison, housing about 1,000 women of all security levels, from minimum to maximum. The population comprises even proportions of black and white women, with a lower share of Latina women. ${ }^{1}$ Ages range from 18 to over 80; average age is 36 . Average length of stay is around 3.5 years; stays range from seven months to life. The largest shares of women are convicted of drug offenses and murder; the next most common offenses are larceny and assault.

I visited Mapleside two to four days per week. My field notes chronicled what I witnessed, along with quotes taken down verbatim in my notebook in real time, totaling nearly 900 single-spaced pages. I coded field notes using the software Nvivo based on emergent themes. At Mapleside, I gained research access to observe activities in the "Main Hall", the building that housed the gym, dining hall, classrooms, computer lab, volunteer coordinator's office, religious library, and chaplain's office. I observed a range of everyday activities, from watching inmates eat lunch to teasing each other in the hallway, to writing essays for college courses in the computer lab. I spent one to seven hours per week doing office work for Chaplain Harper, the full-time chaplain on staff, herself a black Baptist in her mid-50s. I helped with photocopying, filing, mailing letters, making phone calls, taking messages, and even sitting in as an outside volunteer at religious activities, which some prison staff called "babysitting". My office work allowed me to witness Chaplain Harper counseling inmates, managing volunteers, organizing programs, and processing paperwork. These activities made me a familiar face, which granted me access to almost every room in the Main Hall. Because I could position myself in a variety of rooms and corridors, I witnessed countless interactions between inmates, both in front of and beyond the surveillance of prison guards, who are called corrections officers ("officers", from here on).

Beyond informal observations, I conducted formal observations of programs in the Main Hall. Religious programs are a key aspect of prison life for women (Ellis, 2017a). I observed scriptural studies and worship services for a range of faith traditions, including Catholic, Protestant, Jewish, and Sunni Muslim groups. ${ }^{2}$ Outside prison, religious institutions are among the most racially segregated institutions in the U.S., and Sunday morning "the most segregated hour" (Dougherty, 2003; Emerson \& Kim, 2003; Emerson \& Smith, 2001; Hadaway, Hackett, \& Miller, 1984). At Mapleside, religious programs varied in their degree of racial composition. The Sunni Muslim group of about 50 was entirely comprised of black inmates; the Jewish group of about 15 was entirely comprised of white inmates. Among the Catholic group of about 70-of whom approximately 19 attended weekly-on average, $71 \%$ were white, $18 \%$ were black, $12 \%$ were Hispanic or Latina, and less than $1 \%$ were Asian. Of the 260 Protestant inmates who attended worship services each Sunday, on average, $70 \%$ were black, $29 \%$ were white, and $1 \%$ were Hispanic or Latina. The Protestants were somewhat more racially integrated than similar churches outside prison walls.

A large share of my observations, and the primary focus of this article, zoomed in on the largest religious group at Mapleside Prison-the Protestants-who comprised $63 \%$ of the inmate population. This group was an official umbrella affiliation for Baptist, African Methodist Episcopal, Pentecostal, Apostolic, and nondenominational Christians. ${ }^{3}$ The Protestant group held a

\footnotetext{
${ }^{1}$ Absolute numbers withheld to protect the identity of the prison.

2 Smaller religious groups, such as Nation of Islam, Wicca, Lutheran, and Jehovah's Witness, held meetings beyond my access.

3 The largest religious group at Mapleside was officially referred to as the "Protestants". Every inmate, upon arrival to prison, fills out a religious preference form, which allows her to attend religious studies and worship services for that group. She may select only one affiliation. Religious affiliation may be changed every 60 days. Those who checked the "Protestant" box comprised $63 \%$ of the inmate population (about 630 out of 1,000 inmates). This
} 
single worship service for an average of 260 inmates each week, with separate Bible studies for each denomination within the umbrella. I observed Sunday church services, Bible studies, and religious self-help programs nearly every day of the week. Additionally, I conducted observations on major holidays, including Good Friday, Easter, Pentecost, Mother's Day, Father's Day, Thanksgiving, and Christmas.

I was prohibited from bringing a tape recorder inside the facility, and private one-on-one interviews were logistically difficult. Nevertheless, thanks to significant coordination by officers, I ultimately conducted formal interviews with 18 inmates. Finally, I accessed public court records to verify conviction and sentence length for the inmates described in this manuscript.

\section{Findings}

Incarcerated women represent some of the most disadvantaged Americans with respect to race, class, and gender. This case study presents a unique opportunity to consider how religious leaders construct an "ideal" religious self with respect to multiple dimensions of inequality. Religious leaders who volunteered at Mapleside modeled femininity and preached that inmates should embody feminine submissiveness to live up to religious ideals. Furthermore, they preached that inmates should seek a "man of God" to marry post-release. Both the manifestation of femininity and the expectation of marrying a "man of God" aligned with normative assumptions around race, gender, and social class that were out of reach for many incarcerated women, at least while in prison. These findings suggest that constructions of the ideal religious self are defined in potentially problematic ways by those privileged enough to control the narrative.

\subsection{Modeling Femininity}

"It's so distracting to me, the things they wear", Chanel sighed. Chanel is an early 40s black inmate serving time for a financial crime, and is one of the many women at Mapleside who regularly commented on volunteers' appearances. That Wednesday afternoon, Chanel and $\mathrm{Ja}$, an early 20 s black inmate serving a couple years for drug distribution, sat together in the back of a classroom in the Main Hall. Rather than pay attention to Bible study, they compared notes on volunteers' outfits at the Easter Sunday worship service a few days prior. They noticed every detail: "I love the pencil skirt", Ja remarked about Elder Desirée, a black Baptist volunteer in her early 40s who had paired her skirt with a hot pink blouse and matching hot pink high heels. Chanel agreed. Ja noticed the gold Rolex watch on one volunteer's wrist, and Chanel remembered that Chaplain Harper was wearing red heels. Ja chimed in: "It was like a two-inch heel". Chanel and Ja sized up every detail of religious leaders' fashion choices. Like many inmates I spoke to, they noticed that the majority of volunteers were black women with well-tailored wardrobes.

At any given religious program, most volunteers conformed to a curated, highly feminine, businessprofessional style. They routinely wore polished pantsuits or fitted dresses. Volunteers paired their outfits with pointy high heels ranging from shiny pumps to strappy leopard print slingbacks. One volunteer even wore a light blue ball gown and a tiara to the Christmas evening service at Mapleside, conjuring a Cinderellalike impression. Volunteers' hair was often dyed and pressed, worn straight without a single hair out of place, in intricately-styled braids and up-dos. Their nails were almost always professionally polished, and their faces perfectly covered in glossy makeup. Most volunteers wore sparkling jewelry. I spotted dangling earrings, ruby rings, and chunky beaded necklaces. Reverend Mona, a Pentecostal volunteer, showed up wearing a rotation of glitzy, colorful eyeglasses, rarely repeating a debut. "I love my adornment", she confessed during a Ministry class she was teaching, "I love my matching earrings and necklaces". When Reverend Mona and other volunteers entered the room, a waft of floral perfume followed; their confident, feminine presence was all the more apparent as they stood poised and smiled warmly.

Perfume was contraband for prisoners. In fact, prisoners could not easily mirror volunteers' feminine style at all. They were restricted to prison-issued tan sweats, with tan t-shirts for the hot summer months and thicker khaki jackets in the cold winter months. Most outerwear, including sweatshirts and sweatpants, were stamped with large, white "D.O.C." lettering. Lexi, a 40-year-old Jewish inmate, despaired: "I miss clothes. I'm so sick of beige". In fact, other colors were so rare that when Estrella, a Pentecostal inmate in her 30s, donned magenta winter gloves before braving the frigid walk back to her housing unit, she giggled: "I love 'em, they're not beige!" As for accessories, inmates were permitted a watch, a wedding band, and small stud earrings. Inmates could wear a necklace only if it was religious; many wore a small cross or crucifix around their necks. The women at Mapleside could customize their hair by braiding it, straightening it, or curling it, but they were permitted only one hairclip at a time. "You got to get creative in here", said Una, an early 40s black Protestant inmate, while showing off her eyeglass frames. Una had painted what were previously black frames using teal nail polish topped with a layer of glitter, making them colorful and sparkly. Inmates did what they could to express their style, but given the constraints of the prison rules, the divide was stark between volunteers' feminine, professional-looking style and inmates' casual tan uniforms.

The divide between prisoners' and volunteers' backgrounds did not stop at feminine clothing. Prisoners na-

group is difficult to categorize more precisely because it encompassed a wide range of denominational affiliations, contingent on which outside churches sent volunteer preachers to Mapleside. 
tionwide come from socioeconomically disadvantaged backgrounds and lower educational attainment (Heckman \& LaFontaine, 2010; Pettit \& Western, 2004; Western \& Pettit, 2005). According to the Bureau of Justice Statistics' most recent report, $42 \%$ of all female prisoners have not completed high school or a GED (Harlow, 2003). Compared to $58 \%$ of American women with some college, only $31 \%$ of women prisoners have some college or more (Ewert \& Wildhagen, 2011). Although no official statistics on social class at Mapleside are available, my observations suggested that Mapleside was a relatively typical women's prison in these demographic respects. Many inmates were working class or poor single mothers; a majority had completed some or all of high school but no college. This stood in clear contrast to most volunteers, who presented as middle-class women, many of whom routinely mentioned the graduate degrees they had earned, and some even disclosed their six-figure incomes.

Why do these stark differences between inmates and religious volunteers matter? Inmates did not have access, both due to economic disadvantage and prison regulations, to the same expressions of femininity available to religious volunteers. These mismatches around social class and gender expression are a starting point in understanding how the ideal religious self constructed by volunteers was out of reach for most incarcerated women. These incongruities between inmates and volunteers became even more noteworthy in light of the lessons of feminine submission that volunteers preached.

\subsection{Preaching Feminine Submission}

Despite the profound issues of race and class in the prison setting, religious volunteers rarely mentioned these aspects of stratification (Ellis, 2017a). Instead, a majority of their preaching focused on love, gender traditionalism in marriage, and feminine submission. "God set up the order in this world, for men to have dominion", Reverend Mona explained one afternoon at her weekly Ministry class to a group of some of Mapleside's most devout inmates. Attending Reverend Mona's class was voluntary, and generally the 25 or so inmate students eagerly attended to learn how to minister. That day, like every day, Reverend Mona was dressed to the nines. She wore a skirt suit and dangling pearl earrings with a matching pearl necklace. Her hair was perfectly coiffed into a tightly braided top knot.

A happily married Pentecostal minister, Reverend Mona repeatedly promoted gender traditionalism in her lessons. She once professed that she disparaged gender equality in her own marriage because "God set a natural order. First, it's man, then woman, then family. You're not partners-it's not equality". Reverend Mona argued that this "natural order" of the family ultimately benefited women: "I like that, because if something goes wrong in a marriage, God goes after the husband first". Lacking responsibility meant lacking blame. She contin- ued: "I'm happy with it that way. I'm glad the bills are in my husband's name. If there's a problem? Talk to him". With this, Reverend Mona cheerfully pointed her finger at the air next to her, conjuring the image of a responsible husband by her side.

These messages of gender traditionalism are not out of the ordinary for conservative Christians (Perry \& Whitehead, 2016; Pevey, Williams, \& Ellison, 1996), although generally less common among black Protestants (Glass \& Jacobs, 2005; Glass \& Nath, 2006). Feminine submissiveness comes with the territory. "Remember, you're his helpmeet", Reverend Mona warned. Men's authority as head of household was part of the "natural order", but there were limits. As Miss J, a Pentecostal preacher, warned: "If your husband [is] telling you to trick [sell sex], that's not God's plan. If your husband [is] beating you, that's not God's plan for you". Implicit in these words of caution were some assumptions Miss J made about inmates' male partners. Miss J, who has been married for over three decades, anticipated that some inmates' husbands might be physically violent or try to prostitute their wives. This further demonstrates they ways religious leaders relied on their perceptions of inmates' social backgrounds to craft their messages.

Carla's story illustrates the gravity of these messages well. Carla is a late 40 s black inmate serving five years for theft. She underwent a religious transformation while in prison, and began attending AME Bible study every week. "I'm totally dependent on God now", Carla said. "Before, my life has been about money, property, and prestige. Now, I pray to God to allow me to become the woman he intended". Religious messages around being a "good" Christian woman rubbed off on Carla, and she planned to prioritize her womanhood over her financial goals once released.

Not limited to Christian groups, Muslim volunteers likewise promoted submission. Similarities among religious messages may be expected given the Protestantization of the prison chapel (Dubler, 2013). Sister McMillan, a mid-50s black volunteer dressed in a flowing black khimar, instructed to her class of Muslim inmates: "Guard your voice. Some men might fall for a woman just by hearing her voice. Remember to talk low". Similarly, when the more seasoned inmates shared their wisdom with newer converts to Islam, they repeated the same sorts of messages. Ronnie, a 25-year-old black Muslim inmate serving seven years for assault, explained: "I just look down slightly. [At] not just a Muslim man but any man....That was one of those things that was hard for me at first". Maya, a mid-40s black inmate serving a 25 year sentence for attempted murder, who spearheaded Muslim activities at Mapleside, chimed in: "If you look back at him, that's showing interest....Women are responsible for their own modesty. It's our responsibility not to send the wrong message". Feminine submissiveness was a surprisingly common topic in a setting that housed only women.

To fully submit, maintaining idealized feminine characteristics was key. At Reverend Mona's weekly Ministry 
class, during a lesson about the Book of Esther in which Esther makes preparations to meet with the king, Reverend Mona took the opportunity to explain: "There is a way to prepare your body for a man to enter you. It involves fasting, a certain amount of oils, and a certain amount of bathing. I don't care if you been with 19 men, that will make it feel like he is entering a virgin". Henrietta, a mid-50s black Christian inmate sitting in the back row, cackled: "Say what oil it was again?" The other women in the classroom laughed. Reverend Mona gently replied: "It was the oils that Jesus Christ used to anoint himself: myrrh, frankincense, and certain kinds of bath salts". While a Ministry class could focus on any number of religious topics, Reverend Mona chose to emphasize the importance of becoming sexually desirable to men. Moreover, she made assumptions about inmates' sexual experiences, disparaging "19 men" as a marker of promiscuity she believed was a realistic estimate for at least some of the inmates present. Reverend Mona continued: "And if you feel like a virgin every time, he is going to give you everything you ask for". This received several audible "Amens" from the group of inmates. By suggesting that inmates strategically prepare their bodies to "feel like a virgin", Reverend Mona was making assumptions about inmates' sexual identities and sexual histories. Furthermore, the enticement that a man would "give you everything you ask for" suggested that inmates should expect to be subordinate to men and could look forward to men's paternalistic generosity in return.

\subsection{Finding a "Man of God"}

To be submissive was to be a proper woman, according to the religious volunteers. As such, it followed that inmates were encouraged to look for a "man of God" to marry after they were released from prison. After all, Reverend Mona insisted, "God never meant for women to be making decisions by themselves". After a beat, she continued: "We can, but look at Eve". Demeaning women's ability to make sound decisions, Reverend Mona encouraged inmates to seek guidance from men post-release. "[W]hen you go out, seek...someone who gives wisdom", she suggested. The dominant religious messages at Mapleside encouraged inmates to be feminine through submissiveness to a man, but he must be a man "of God".

In a similar message, during his sermon one night at a Sunday night worship service, Pastor O'Neill, one of the rare male volunteers, preached that female inmates should try to find a male romantic partner at church after they are released. "When you get out [of prison], you can come to my church and find a real man", Pastor O'Neill grinned, poking fun at the gender identity of the inmates present. "Your church [at Mapleside] is $60 \%$ women and 40\%_" at this, Pastor O'Neill cut himself off and scrunched his face, shrugging. Pastor O'Neill was referring to the male-presenting inmates in the room, of which there were a substantial proportion. ${ }^{4}$ Some inmates began to cheer and laugh, finding levity in Pastor O'Neill's mockery. Femininity and submissiveness to a male partner were entirely out of sync for the lesbian and male-presenting inmates at Mapleside. However, according to these top-down normative messages, meeting a male romantic partner at church was ideal.

Many inmates reported that they adopted the ideals of the volunteer ministers and planned to start a relationship with a "man of God" post-release. Coretta, a mid40s black inmate serving 40 years for murder, frequently attended Miss J's Wednesday night classes. She said she would seek "a man of God....I'm looking for a real man who will be the head of the house and all that". This was especially poignant given that Coretta's co-conspirator in the murder charge was her former boyfriend.

In fact, it is not uncommon for women who are incarcerated for violent crimes to be charged as codefendants alongside their male romantic partners who masterminded the crime (Jones, 2008). Bev, an early 30s white inmate, pointed out this sad irony. "For my codefendant-my boyfriend-God was the furthest thing from him. He thought God was dumb. That's why I'm here". The notion of finding an upstanding, god-fearing man seemed particularly appealing for a population used to men leading them down dark paths.

The desire to avoid men of ill-repute was so strong that Felicia, an ebullient early 30s black inmate who participated in a number of Protestant programs, shared that she planned to avoid dating men who were, in her view, not "real" Christians. "I know I want to be celibate when I go home-go out [date] for real, like walks in the park, go out dancing", Felicia proclaimed. "I got this other friend who say he a Christian, but he don't get it.... know he's not good for me". Felicia was skeptical of her male friend's advances because she doubted his religiosity. The desire to find a "man of God" ran so deep that inmates like Felicia were prepared to reject the advances of interested men, even after years in prison, deprived of heterosexual intimacy.

In the same vein, Maya, the mid-40s black Muslim inmate serving a 25 -year sentence, believed it wise to follow the guidance of a "man of God". She stated: "People criticize that Muslim women just have to do what men say. But they don't understand that if you're with a man of God, he will only say that you have to do something if it will help you". A "man of God", in Maya's view, is benevolent and worthy of her submission. Ronnie, the 25-year-old black Muslim inmate serving seven years for assault, likewise explained: "I want to be more on my din [religion], and I want a man who on his din". Given how important religion was for many inmates at Mapleside, they actively sought men equally committed to religion.

\footnotetext{
${ }^{4}$ Identifying as a "boi" was relatively common at Mapleside. As one inmate told me: "You'll have women that come in, and when they first get here, they're looking for nail polish - they're feminine. Then all of a sudden, before you know it, they look like a boy". This may be related to the high rates of inmate romantic relationships behind bars (e.g., Owen, 1998; Severance, 2005).
} 
During my observations, only one inmate openly questioned the advice to seek a man of God to marry. Iris, a black Protestant inmate in her early 50s, did not subscribe to the idea that she needed to find a partner who was already religious. "They say you should marry a Christian", Iris began, "but you could be with someone who learns by observing you". Iris hoped that her newfound religiosity would rub off on her partner.

For inmates like Iris who had stable male partners at home, women's emotional labor was required to maintain the relationship. Religious volunteers cautioned that inmates should avoid alienating these men with their newfound religiosity. "When you go home all 'God, God, God', remember those people who have been waiting for you", Miss J explained. "They'll notice that you've changed. Don't leave 'em behind". Loved ones should come along for the spiritual ride, but women should be prepared to help ease that transition. Ideally, existing male partners of female inmates would become men of God, but women's emotional labor would need to be part of that process.

Overall, religious messages encouraged female inmates to "do religion" by engaging in feminine submissiveness to a male head of household. As Reverend Mona taught: "The foundation of ministry is love". Of all possible topics to discuss related to religion for prisoners (cf. Dubler, 2013; Johnson, 2017), volunteers chose to emphasize the ways to embody femininity and submission as core lessons of spiritual growth. However, as the next section demonstrates, these messages were loaded not only with gender traditionalist values, but also normative raced and classed expectations that were structurally unavailable to most incarcerated women.

\subsection{Out of Sync: Race, Class, Gender, and the Normative Religious Self}

The expectation to find a "man of God" to whom to be submissive reveals the ways in which middle-class volunteers' messages were out of sync with the socioeconomic disadvantage of incarcerated women. First and foremost, incarcerated women were temporarily isolated from the marriage market by virtue of being imprisoned. Although most volunteers were married, inmates' access to "men of God" while in prison was decidedly limited. Given this constraint, preachers' decision to emphasize feminine submission and finding of man of God out of all possible religious teachings is even more conspicuous.

Another difficulty in finding a "man of God" to marry relates to the fact that men are generally less religious than women, attending church significantly less often (Chatters et al., 1999; Roth \& Kroll, 2007; Schnabel, 2015). Inmates were well aware of this sex ratio imbalance. At the Protestant Youth Bible study one week, while screening a video of a church service at a well-known local Baptist church, Gabriel, the early 40 s black inmate leading the class commented audibly on the video: "I don't know why, but I like to see men shout". June, a younger in- mate, chimed in: "That's what I like to see-black men in church". For Gabriel and June, seeing black men in church was desirable and noteworthy.

Furthermore, once released, formerly incarcerated women's chances of finding a husband might be restricted by their socioeconomic disadvantage. The shortage of "marriageable" men in poor, black communities in particular-to which many incarcerated women will return-makes this expectation even more challenging (Sawhill \& Venator, 2001; Wilson, 1987, 1996). Prior research has shown that marriage has declined among the working class and poor (Anderson, 1999; Cherlin, 2010; Edin \& Kefalas, 2005), who view marriage as desirable, but struggle to attain the financial stability they deem necessary prior to marrying (Edin \& Kefalas, 2005; Edin \& Nelson, 2013; Smock, Manning, \& Porter, 2005; Sweeney, 2002). This may be especially true for women of color given the role of work in widening the marriage gap among African Americans (Wilson, 1987, 1996). Due to their economic vulnerability post-release and challenges in finding employment (Loeffler, 2013; Pager, 2003; Ramakers, Nieuwbeerta, Dirkzwager, \& Van Wilson, 2014; Western, 2002), former prisoners are not well-positioned to attain their desired financial stability before marriage. On top of financial barriers, women who have been incarcerated face an even greater social stigma than formerly incarcerated men (Roberts, 2004), which could lead to lower marriageability (Apel, 2016; Baćak \& Kennedy, 2015).

Despite being isolated from the opportunity to meet new men while incarcerated, Sunni inmates gained a significant advantage over Protestant inmates in successfully finding a "man of God": they had matchmakers. A wadi (matchmaker) was a Muslim elder to whom a Muslim inmate could write to request he find her a suitable partner. Muslim inmates saw this as a realistic resource to draw on. Maya, the older, more erudite Muslim inmate, advised Ronnie that she could tell her matchmaker exactly what she was looking for, even physically:

You can't wake up every morning next to someone who you think is a monster. The sex isn't going to be good and you're not going to be happy. You can absolutely tell him [the matchmaker]. That's the wadi's job, to find out exactly what you want.

Ronnie giggled, giddy with this new information: "Okay, so I can tell him I want a tall, dark man?" Maya smiled demurely. A month prior, while incarcerated, Maya wed a Muslim man thanks to a wadi. For Muslim inmates, a matchmaker could facilitate finding a "man of God" to marry.

Absent this liaison in the Protestant community, Protestant inmates would have a much more difficult time finding a religious partner. Given contemporary prerequisites for marriage and the relatively lower proportion of religious men, this middle-class religious message that encouraged inmates to find a "man of God" to marry 
post-release were largely out of sync with attainable realities, at least in the immediately foreseeable future. This disparity highlights the ways class, race, and gender are woven together to construct an ideal religious self that may be hard to attain among a population of inmates disadvantaged in all three categories.

\section{Conclusion}

At Mapleside Prison, religious leaders promoted femininity and submission in a gender traditionalist family structure. These messages are consistent with prior research on women's prisons that shows how rules, regulations, and rehabilitative programs encourage female offenders to embody conventional norms around gender and sexuality (Haney, 2010; McCorkel, 2013). This article shows how class and race come to bear on gendered religious messages in prison, promoting distinctly middle-class expectations for marriage post-release that are largely unattainable for most disadvantaged inmates.

The contributions of this article are threefold. First, studies of gendered religious selves must take variables like race and class into account when assessing the ways religion is practiced and performed. Given that gender, race, and class overlap in multiplicative ways (Singh, 2015), understanding the ways religious selves are performed requires interrogating these overlaps. "Doing religion" is linked not only with "doing gender", but also within the constraints of the social constructions of race and class.

Second, this article suggests that studies of the construction of gendered religious selves must consider the broader context of top-down definitions of the religious self. Religious selves are not defined in a vacuum. While individuals actively decide how to practice their faith (Avishai, 2008; Davidman, 2014; Rao, 2015), they do so in a context substantially shaped by top-down views from religious authorities (Ellis, 2015, 2017b; Moon, 2004, 2005). This means closely considering how religious leaders draw upon their race, class, and gender positions when constructing notions of an ideal religious self.

Finally, religious selves do not play out in a neutral landscape. When religious subjects "do religion", they do so within the broader environment of stratification. Social positions with respect to race, class, and gender form an intersectional religious self that could ultimately reinforce stratification by upholding normative beliefs that further disadvantage non-normative groups. Topdown constructions of the "ideal" religious self could reinforce stratification, as they involve embodying expectations that may be out of reach for the most disadvantaged adherents.

Intersectionality matters in understanding how the religious self is constructed. Dominant discourses around the religious self play an active role in how laypersons "do religion", as evidenced by the extent to which Mapleside inmates adopted the messages preached by religious volunteers. Dominant messages, however, rely on specific notions of ideal appearance and conduct that are shaped by privileged positions with respect to race, class, and gender. The very same institutions that perpetuate inequality through segregated pews and constraining doctrine also define religious selves in ways that maintain inequality by promoting ideals that may be out of reach for the least advantaged congregants.

\section{Acknowledgements}

The author thanks Melissa Wilde, Annette Lareau, Randall Collins, Patricia Tevington, Aliya Rao, Lindsay Glassman, Pete Harvey, and the anonymous reviewers for their helpful feedback on versions of this manuscript. Thanks to Amanda Miller for her research assistance. This work was supported by the American Council of Learned Societies, the Association for the Sociology of Religion, the Louisville Institute, the National Science Foundation [DGE-0822], the Religious Research Association, and the Woodrow Wilson Foundation. Any opinion, findings, and conclusions or recommendations expressed in this material are those of the author and do not necessarily reflect the views of the National Science Foundation.

\section{Conflict of Interests}

The author declares no conflict of interests.

\section{References}

Anderson, E. (1999). Code of the street: Decency, violence, and the moral life of the inner city. New York, NY: W. W. Norton \& Company.

Apel, R. (2016). The effects of jail and prison confinement on cohabitation and marriage. The ANNALS of the American Academy of Political and Social Science, 665(1), 103-126.

Avishai, O. (2008). Doing religion in a secular world: Women in conservative religions and the question of agency. Gender and Society, 22(4), 409-433.

Avishai, O. (2016). Theorizing gender from religion cases: Agency, feminist activism, and masculinity. Sociology of Religion, 77(3), 261-279.

Avishai, O., Jafar, A., \& Rinaldo, R. (2015). A gender lens on religion. Gender \& Society, 29(1), 5-25.

Baćak, V., \& Kennedy, E. H. (2015). Marginal structural models: An application to incarceration and marriage during young adulthood. Journal of Marriage and Family, 77(1), 112-125.

Baker, J., \& Whitehead, A. (2016). Gendering (non)religion: Politics, education, and gender gaps in secularity in the United States. Social Forces, 94(4), 1623-1645.

Bartkowski, J. P. (2004). The promise keepers: Servants, soldiers, and godly men. Brunswick, NJ: Rutgers University Press.

Bartkowski, J. P., \& Ghazal-Read, J. (2003). Veiled submis- 
sion: Gender, power, and identity among evangelical and Muslim women in the United States. Qualitative Sociology, 26(1), 71-92.

Bulanda, J. R. (2011). Doing family, doing gender, doing religion: Structured ambivalence and the religion-family connection. Journal of Family Theory \& Review, 3(3), 179-197.

Burke, K. C. (2012). Women's agency in gender-traditional religions: A review of four approaches. Sociology Compass, 6(2), 122-133.

Butler, J. (1990). Gender trouble: Feminism and the subversion of identity. New York, NY: Routledge.

Byng, M. D. (1998). Mediating discrimination: Resisting oppression among African-American Muslim women. Social Problems, 45(4), 473-487.

Cadge, W. (2004). Gendered religious organizations: The case of Theravada Buddhism in America. Gender \& Society, 18(6), 777-793.

Casselberry, J. (2017). The labor of faith: Gender and power in Black Apostolic Pentecostalism. Durham: Duke University Press.

Chatters, L. M., Taylor, R. J., \& Lincoln, K. D. (1999). African American religious participation: A multisample comparison. Journal for the Scientific Study of Religion, 38(1), 132-145.

Cherlin, A. J. (2010). The marriage-go-round: The state of marriage and the family in America today. New York, NY: Vintage.

Chong, K. H. (2006). Negotiating patriarchy: South Korean Evangelical women and the politics of gender. Gender \& Society, 20, 697-724.

Collins, P. H. (2000). Black feminist thought: Knowledge, consciousness, and the politics of empowerment. New York, NY: Routledge.

Collins, P. H. (2015). Intersectionality's definitional dilemmas. Annual Review of Sociology, 41, 1-20.

Crenshaw, K. W. (1989). Demarginalizing the intersection of race and sex: A Black feminist critique of antidiscrimination doctrine, feminist theory and antiracist politics. Chicago Legal Forum, 1989(1), 139-167.

Crenshaw, K. W. (1991). Mapping the margins: Intersectionality, identity politics, and violence against women of color. Stanford Law Review, 43(6), 1241-1299.

Davenport, L. D. (2016). The role of gender, class, and religion in biracial Americans' racial labeling decisions. American Sociological Review, 81(1), 57-84.

Davidman, L. (1991). Tradition in a rootless world: Women turn to Orthodox Judaism. Berkeley, CA: University of California Press.

Davidman, L. (2014). Becoming un-Orthodox: Stories of ex-Hasidic Jews. Oxford, NY: Oxford University Press.

Dougherty, K. D. (2003). Monochromatic is church membership? Racial-ethnic diversity in religious community. Sociology of Religion, 64(1), 65-85.

Dubler, J. (2013). Down in the chapel: Religious life in an American prison. New York, NY: Farrar, Straus, and Giroux.
Ecklund, E. H. (2003). Catholic women negotiate feminism: A research note. Sociology of Religion, 64(4), 515-524.

Edin, K., \& Kefalas, M. J. (2005). Promises I can keep: Why poor women put motherhood before marriage. Berkeley, CA: University of California Press.

Edin, K., \& Nelson, T. J. (2013). Doing the best I can: Fatherhood in the inner city. Berkeley, CA: University of California Press.

Ellis, R. (2015). Outreach and exclusion: Jewish denominational marketing in the 20th century. Journal for the Scientific Study of Religion, 54(1), 38-56.

Ellis, R. (2017a). In this place called prison: How religion structures the social world of incarcerated women (Doctoral dissertation). University of Pennsylvania, Philadelphia, PA.

Ellis, R. (2017b). Silent disagreement: Microinteractional solutions to moral dissent among Catholic converts. Journal for the Scientific Study of Religion, 56(2), 383-397.

Emerson, M. O., \& Kim, K. C. (2003). Multiracial congregations: An analysis of their development and a typology. Journal for the Scientific Study of Religion, 42(2), 217-227.

Emerson, M. O., \& Smith, C. (2001). Divided by faith: Evangelical religion and the problem of race in America. Oxford: Oxford University Press.

Ewert, S., \& Wildhagen, T. (2011). Educational characteristics of prisoners: Data from the ACS. Paper presented at the Annual Meeting of the Population Association of America, Washington, DC.

Fowler, R. B., Hertzke, A. D., Olson, L. R., \& Den Dulk, K. R. (2013). Religion and politics in America: Faith, culture, and strategic choices. Boulder, CO: Westview Press.

Glass, J., \& Jacobs, J. (2005). Childhood religious conservatism and adult attainment among black and white women. Social Forces, 8(1), 555-579.

Glass, J., \& Nath, L. E. (2006). Religious conservatism and women's market behavior following marriage and childbirth. Journal of Marriage and Family, 68(3), 611-629.

Green, J. C. (2007). The faith factor: How religion influences American elections. Westport, СT: Greenwood Publishing Group.

Hadaway, C. K., Hackett, D. G., \& Miller, J. F. (1984). The most segregated institution: Correlates of interracial church participation. Review of Religious Research, 25(3), 204-219.

Haney, L. A. (2010). Offending women: Power, punishment, and the regulation of desire. Berkeley, CA: University of California Press.

Harlow, C. W. (2003). Education and correctional populations (Bureau of Justice Statistics Special Report). Washington, DC: Bureau of Justice Statistics. Retrieved from https://eric.ed.gov/?Id=ED477377

Heath, M. (2003). Soft-boiled masculinity: Renegotiating gender and racial ideologies in the Promise Keepers movement. Gender \& Society, 17(3), 423-444. 
Heckman, J. J., \& Lafontaine, P. A. (2010). The American high school graduation rate: Trends and levels. The Review of Economics and Statistics, 92(2), 244-262.

Ingersoll, J. (2003). Evangelical Christian women: War stories in the gender battles. New York, NY: NYU Press.

Irby, C. A. (2014). Dating in light of Christ: Young evangelicals negotiating gender in the context of religious and secular American culture. Sociology of Religion, 75(2), 260-283.

Johnson, A. (2017). If I give my soul: Faith behind bars in Rio de Janeiro. Oxford, NY: Oxford University Press.

Jones, S. (2008). Partners in crime: A study of the relationship between female offenders and their codefendants. Criminology \& Criminal Justice, 8(2), 147-167.

Karim, J. (2008). Across ethnic boundaries: Women's movement and resistance in the Chicago ummah. In American Muslim women: Negotiating race, class, and gender with the ummah (pp. 89-124). New York, NY: NYU Press.

Kaufmann, K. M., \& Petrocik, J. R. (1999). The changing politics of American men: Understanding the sources of the gender gap. American Journal of Political Science, 43(3), 864-887.

Keister, L. A. (2003). Religion and wealth: The role of religious affiliation and participation in early adult asset accumulation. Social Forces, 82(1), 175-207.

Keister, L. A. (2008). Conservative Protestants and wealth: How religion perpetuates asset poverty. American Journal of Sociology, 113(5), 1237-1271.

Keister, L. A. (2011). Faith and money: How religion contributes to wealth and poverty. New York, NY: Cambridge University Press.

Khurshid, A. (2015). Islamic traditions of modernity: Gender, class, and Islam in a transnational women's education project. Gender \& Society, 29(1), 98-121.

Leamaster, R. J., \& Subramaniam, M. (2016). Career and/or motherhood? Gender and the LDS church. Sociological Perspectives, 59(4), 776-797.

Loeffler, C. E. (2013). Does imprisonment alter the life course? Evidence on crime and employment from a natural experiment. Criminology, 51(1), 137-166.

Mahmood, S. (2004). Politics of piety. Chicago, IL: University of Chicago Press.

Mattis, J. S. (2002). Religion and spirituality in the meaning-making and coping experiences of African American women: A qualitative analysis. Psychology of Women Quarterly, 26(4), 309-321.

McCall, L. (2001). Complex inequality: Gender, class, and race in the new economy. New York, NY: Routledge.

McCloud, S. (2007). Putting some class into religious studies: Resurrecting an important concept. Journal of the American Academy of Religion, 75(4), 840-862.

McCorkel, J. (2013). Breaking women: Gender, race, and the new politics of imprisonment. New York, NY: NYU Press.

Moon, D. (2004). God, sex, and politics. Chicago, IL: University of Chicago Press.
Moon, D. (2005). Discourse, interaction, and testimony: The making of selves in the U.S. Protestant dispute over homosexuality. Theory and Society, 34(5/6), 551-577.

Nyhagen, L. (2017). The lived religion approach in the sociology of religion and its implications for secular feminist analyses of religion. Social Compass, 64(4), 495-511.

Owen, B. (1998). "In the mix": Struggle and survival in a women's prison. Albany, NY: SUNY Press.

Ozorak, E. W. (1996). The power, but not the glory: How women empower themselves through religion. Journal for the Scientific Study of Religion, 35(1), 17-29.

Pager, D. (2003). The mark of a criminal record. American Journal of Sociology, 108(5), 937-975.

Perry, S. L., \& Whitehead, A. L. (2016). For better or for worse? Gender ideology, religious commitment, and relationship quality. Journal for the Scientific Study of Religion, 55(4), 737-755.

Pettit, B., \& Western, B. (2004). Mass imprisonment and the life course: Race and class inequality in U.S. Incarceration. American Sociological Review, 69(2), 151-169.

Pevey, C., Williams, C. L., \& Ellison, C. G. (1996). Male god imagery and female submission: Lessons from a southern Baptist ladies' bible class. Qualitative Sociology, 19(2), 173-193.

Prickett, P. J. (2015). Negotiating gendered religious space: The particularities of patriarchy in an African American mosque. Gender \& Society, 29(1), 51-72.

Pyle, R. E. (2006). Trends in religious stratification: Have religious group socioeconomic distinctions declined in recent decades? Sociology of Religion, 67, 61-79.

Ramakers, A., Nieuwbeerta, P., Dirkzwager, A., \& Van Wilson, J. (2014). Imprisonment length and postprison employment prospects. Criminology, 52(3), 399-427.

Rao, A. H. (2015). Gender and cultivating the moral self in Islam: Muslim converts in an American mosque. Sociology of Religion, 76(4), 413-435.

Roberts, D. E. (2004). The social and moral cost of mass incarceration in African American communities. Stanford Law Review, 56, 1271-1305.

Roth, L. M., \& Kroll, J. C. (2007). Risky business: Assessing risk preference explanations for gender differences in religiosity. American Sociological Review, 72(2), 205-220.

Sawhill, I., \& Venator, J. (2001). Is there a shortage of marriageable men? Brookings. Retrieved from https://www.brookings.edu/research/is-therea-shortage-of-marriageable-men

Schnabel, L. (2015). How religious are American women and men? Gender differences and similarities. Journal for the Scientific Study of Religion, 54(3), 616-622.

Schnabel, L. (2017a). Gendered religiosity. Review of Religious Research, 59(4), 547-556.

Schnabel, L. (2017b). More religious, less dogmatic: Turn- 
ing a gender lens on gender differences in religion (Doctoral Dissertation). Indiana University, Bloomington, IN.

Severance, T. A. (2005). 'You know who you can go to': Cooperation and exchange between incarcerated women. The Prison Journal, 85(3), 343-367.

Shahar, R. N.-B. (2015). At 'Amen meals' it's me and God-Religion and gender: A new Jewish women's ritual. Contemporary Jewry, 35(2), 153-172.

Singh, J. (2015). Religious agency and the limits of intersectionality. Hypatia, 30(4), 657-674.

Smilde, D. (2007). Reason to believe: Cultural agency in Latin American Evangelicalism. Berkeley, CA: University of California Press.

Smith, C., \& Faris, R. (2005). Socioeconomic inequality in the American religious system: An update and assessment. Journal for the Scientific Study of Religion, 44, 95-104.

Smock, P. J., Manning, W. D., \& Porter, M. (2005). 'Everything's there except money': How money shapes decisions to marry among cohabitors. Journal of Marriage and the Family, 67(3), 680-696.

Spelman, E. V. (1988). Inessential woman: Problems of exclusion in feminist thought. Boston, MA: Beacon Press.

Stark, R. (2002). Physiology and faith: Addressing the "universal" gender difference in religious commitment. Journal for the Scientific Study of Religion, 41(3), 495-507.

Sumerau, J. E. (2012). "That's what a man is supposed to do": Compensatory manhood acts in an LGBT Christian church. Gender \& Society, 26(3), 461-487.

Sumerau, J. E., \& Cragun, R. T. (2014). The hallmarks of righteous women: Gendered background expectations in the Church of Jesus Christ of Latter-Day Saints.
Sociology of Religion, 76(1), 49-71.

Sumerau, J. E., Cragun, R. T., \& Mathers, L. A. B. (2016). Contemporary religion and the cisgendering of reality. Social Currents, 3(3), 293-311.

Sweeney, M. M. (2002). Two decades of family change: The shifting economic foundations of marriage. American Sociological Review, 67(1), 132-147.

Tevington, P. (in press). 'Too soon to say 'I do?': Religion, social class, and family formation (Doctoral Dissertation). University of Pennsylvania, Philadelphia, PA.

West, C., \& Fenstermaker, S. (2002). Doing gender, doing difference: Inequality, power, and institutional change. New York, NY: Routledge.

West, C., \& Zimmerman, D. H. (1987). Doing gender. Gender \& Society, 1(2), 125-151.

Western, B. (2002). The impact of incarceration on wage mobility and inequality. American Sociological Review, 67(4), 526-546.

Western, B., \& Pettit, B. (2005). Black-white wage inequality, employment rates, and incarceration. American Journal of Sociology, 111(2), 553-578.

Wilde, M., \& Glassman, L. (2016). How complex religion can improve our understanding of American politics. Annual Review of Sociology, 42, 407-425.

Wilson, W. J. (1987). The truly disadvantaged: The inner city, the underclass, and public Policy. Chicago, IL: University of Chicago Press.

Wilson, W. J. (1996). When work disappears: The world of the new urban poor. New York, NY: Vintage.

Yanay-Ventura, G. (2016). Multifaceted religious feminism: The case of modern orthodox feminists in Israel. Sociology and Anthropology, 4(1), 17-28.

Zion-Waldoks, T. (2015). Politics of devoted resistance: Agency, feminism, and religion among Orthodox agunah activists in Israel. Gender \& Society, 29(1), 73-97.

\section{About the Author}

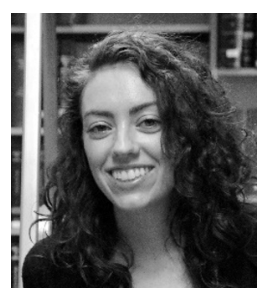

Rachel Ellis is an Assistant Professor of Criminology and Criminal Justice at the University of MissouriSt. Louis. This article is based on a larger project on religious life inside a U.S. state women's prison. Her work has been published in the Journal for the Scientific Study of Religion. 